\title{
KEARIFAN LOKAL MASYARAKAT DALAM MENYIKAPI WARGA RETARDASI MENTAL (STUDI KASUS DI KAMPUNG IDIOT DESA SIDOHARJO KECAMATAN JAMBON KABUPATEN PONOROGO)
}

\author{
Local Wisdom of the Community in Handling Mental Retardation People \\ ( A Case Study of "Kampung Idiot" in Sidoharjo Village, Jambon District, Ponorogo Regency)
}

\author{
Muhammad Hanif*) \\ Program Studi Magister PIPS IKIP PGRI MADIUN \\ *)E-mail: muhhanieff@yahoo.com
}

\begin{abstract}
Sidoharjo village, in Jambon is one of villages in Ponorogo Regency, called as 'Kampong Idiot', since there are many villagers having mental retardation. They also have many disabilities, as a matter of fact they can survive and live quite longer. It certainly happens in accordance with the local wisdom of other villagers, the normal people who live in their surrounding. The research, therefore, aims to analyze and describe local wisdom of the community "Kampung Idiot" Sidoharjo Jambon Ponorogo in handling mental retardation people of Kampung Idiot in Sidoharjo village, Jambon district, Ponorogo regency. The research used descriptive-qualitative. The informants comprised of village officers, socialite, religion leader, youth and all family members of mental retardation people. Data were collected by using in-depth interview, observation, and documentation. Source triangulation was excuted in an effort to validate data and then the data were analyzed by using Strauss and Corbin's Coding model.The local wisdom of Sidoharjo community in handling mental retardation people is a result of relationship among the people in the community, the people and their God, and the people and nature in their surrounding. The local wisdom can be seen from the community's attitudeaccepting mental retardation people as the parts of the community and they are willing to help the mental retardation people do their personal, household and social activities. The local wisdom of the community seems to happen for (1) a belief in the existence of the mental retardation people is tribulation sent by God, providing deep meaning and boon that need to be faced, (2) they are social ethics and responsible moral for the social environment, (3) the norms include advices, prohibition, punishment, and wise words about life.
\end{abstract}

Keywords: local wisdom, attitude, mental retardation people

\section{ABSTRAK}

Desa Sidoharjo Jambon merupakan salah satu kampung di Kabupaten Ponorogo yang disebut "kampung idiot" karena banyak warganya yang mengalami retardasi mental. Warga retardasi mental di kampung ini memiliki banyak keterbatasan namun dapat melangsungkan hidupnya dalam kurun waktu yang relatif lama. Hal itu tentunya terkait dengan sikap arif warga masyarakat di lingkungan sekitarnya. Adapun tujuan penelitian ini adalah untuk menganalisis dan mendeskripsikan kearifan lokal masyarakat Sidoharjo dalam menyikapi warga retardasi mental di "kampung idiot" Sidoharjo Jambon. Penelitian ini mengunakan pendekatan kualitatif-deskriptif. Informan terdiri dari pejabat pemerintah desa, tokoh; masyarakat, agama, dan pemuda, serta keluarga warga retardasi mental. Pengambilan datanya menggunakan wawancara mendalam, observasi, dan pencatan dokumen. Validasi data dengan triangulasi sumber dan analisis datanya dengan model coding Strauss dan Corbin. Hasil penelitian menunjukkan bahwa kearifan lokal masyakat dalam menyikapi warga retardasi mental merupakan hasil dari relasionalitas diantara warga masyarakat, masyarakat dengan Tuhan dan alam. Masyarakat menerima warga retardasi mental sebagai bagian dari dirinya dan berusaha membantunya agar mampu menjalankan aktivitas pribadi, keluarga, dan sosial. Kearifan lokal masyarakat tersebut dipredisposisi oleh; (1) keyakinan bahwa warga retardasi mental merupakan ujian Tuhan yang harus disikapi karena mengandung arti serta hikmah, (2) etika sosial dan tanggungjawab secara moral terhadap lingkungan sosial, (3) norma-norma yang berupa anjuran-anjuran, larangan-larangan, sanksi, dan ungkapan kebijaksanaan akan kehidupan.

Kata kunci: kearifan lokal, sikap, warga retardasi mental

\section{PENDAHULUAN}

Desa Sidoharjo Kecamatan Jambon Kabupaten Ponorogo merupakan salah satu desa yang disebut sebagai "kampung idiot" karena banyak warganya yang mengalami retardasi mental (tunagrahita). Desa lain yang disebut kampung idiot yaitu Desa Krebet Kecamatan Jambon, Desa Karangpatihan dan Pandak Kecamatan Balong. Dari keempat desa tersebut, desa yang paling banyak warganya yang retardasi mental adalah Desa Sidoharjo Kecamatan Jambon. Jumlahnya 138 orang atau mencapai $2,20 \%$ dari jumlah penduduk desa.

Sebutan "kampung idiot" terhadap desa-desa di atas tidaklah tepat karena tidak semua orang yang mengalami retardasi mental adalah idiot, dan tidak semua warga yang cacat adalah retardasi mental.Dari penelitian yang dilakukan sebelumnya ditemukan bahwa selain warga retardasi mental terdapat juga warga yang mengalami kecacatan lain, diantaranya cacat fisik, sakit jiwa, dan lain-lainnya (Hanif dan Afifah, 2015). Mereka itu dikategorikan sebagai Orang Dengan Kecacatan (ODK) dengan rincian seperti tercantum dalam tabel di bawah ini

Hanif dan Asri (2014) juga menyampaikan bahwa banyak warga yang mengalami retardasi mental di Desa Sidoharjo mulai terjadi 1970-an. Hal tersebut disebabkan oleh 
Tabel 1. Data Jumlah Orang dalam Kecacatan dan Retardasi Mental Desa Sidoharjo

\begin{tabular}{ccccccc}
\hline \multicolumn{7}{c}{ Jenis Kecacatan, Orang } \\
Retardasi & Tuna & Tuna & Tuna & Cacat & Gila/ & Jum- \\
Mental & Daksa & Rungu & Wicara & Pisik- & Stress & Lumpuh \\
\hline
\end{tabular}

\begin{tabular}{ccccccc}
138 & 5 & 9 & 3 & 4 & 5 & 164 \\
\hline (Sumber: Hasil & pendataan peneliti bersama FSB, Februari 2015)
\end{tabular}

berbagai faktor, antara lain; gizi buruk, sarana prasarana dan pelayanan kesehatan yang tidak memadai, air tanah yang dikonsumsi sangat rendah kadar yodiumnya, dan ada juga yang berpendapat kejadian ini karena ada kutukan dari leluhur desa "Mbah Bedong". Dengan demikian masyarakat desa ini sudah menjalani hidup bersama dengan warga retardasi mental dalam kurun waktu yang relatif lama.

Warga retardasi mental memiliki banyak keterbatasan namun dapat melangsungkan hidupnya dalam kurun waktu yang lama (Hanif dan Asri, 2013). Hal tersebut tentunya berkaitan warga masyarakat lain yang ada di lingkungan sekitarnya. Sehingga mengundang berbagai pertanyaan antara lain; bagaimana masyarakat menyikapi situasi dan kondisi kemasyarakatan yang diwarnai oleh banyak warga yang mengalami retardasi mental, nilai-nilai apa saja yang dijadikan acuan atau rujukan masyarakat dalam bersikap kepada warga retardasi mental Desa Sidoharjo. Untuk itulah penelitian menarik dan perlu dilaksanakan.

Adapun tujuan penelitian ini adalah untuk menganalisis dan mendeskripsikan sikap masyarakat dan nilai-nilai kearifan lokal yang dijadikan acuan dalam menyikapi warga retardasi mental di Sidoharjo Jambon Ponorogo.

Penelitian urgen dilaksanakan dengan harapan hasilnya dapat dijadikan sumber inspiratif bagi masyarakat agar lebih peduli pada warga yang kurang beruntung seperti retardasi mental tersebut sehingga mereka lebih berdaya dan dapat membangun dirinya dan bersama-sama membangun masyarakat dan bangsanya.

Kearifan lokal (local wisdom) merupakan konsepsi masyarakat lokalitas tertentu tentang hidup. Konsepsi tersebut dilandasi nalar jernih, budi yang baik, dan memuat hal-hal positif. Kearifan lokal juga dimaknai sebagai karya akal budi, perasaan mendalam, tabiat, bentuk perangai, dan anjuran untuk kemuliaan manusia (Soetomo,2012). Hal serupa disampaikan Karo (dalam Theresia,2014) bahwa kearifan lokal adalah gagasan-gagasan atau nilai-nilai, pandanganpandangan setempat (lokal) yang bersifat bijaksana, penuh kearifan, bernilai baik yang tertanam dan diikuti oleh anggota masyarakatnya. Zulkarnain dkk (2008) juga menyampaikan bahwa kearifan lokal yaitu prinsip-prinsip dan cara tertentu yang dianut, dipahami, dan diaplikasikan oleh masyarakat lokal dalam berinteraksi dan berinterelasi dengan lingkungannya dan diformulasikan dalam bentuk sistem nilai dan norma adat. Oleh karena itu untuk memahami kearifan lokal di suatu masyarkat maka perlu menelaah nilai-nilai budaya baik yang hidup di dalam wilayah tersebut.

Nilai-nilai budaya tersebut di atas menurut Koetjaraningrat (2009:153) merupakan konsep-konsep mengenai sesuatu yang ada dalam alam pikiran sebagian besar warga masyarakat yang dianggap bernilai, berharga, dan penting dalam hidup sehingga dapat berfungsi sebagai suatu pedoman yang memberi arah dan orientasi pada kehidupan para warga masyarakat. Menurut C. Kluckhohn dan F. Kluckhohn dalam Koentjaraningrat (2009:154) menyampaikan lima masalah dasar dalam hidup yang dapat digunakan untuk menganalisis secara universal tentang orientasi nilai budaya manusia, yaitu; (1) hakikat dari manusia, (2) hakikat karya, (3) hakikat kedudukan manusia dalam ruang waktu, (4) hakikat hubungan manusia dengan alam sekitarnya, dan (5) hakikat hubungan manusia dengan sesamanya.

Fungsi kearifan lokal sebagaimana dijelaskan di atas selaras dengan pendapat Theresia dkk (2014) dan Soetomo (2012) yaitu sebagai pedoman, pengontrol, dan rambu-rambu untuk berperilaku dalam berbagai dimensi kehidupan baik saat berhubungan dengan sesama maupun dengan alam. Sedangkan bentuk-bentuk kearifan lokal dapat berupa: nilai, norma, etika, kepercayaan, adat-istiadat, hukum adat, dan aturan-aturan khusus.

Kearifan lokal tumbuh dan berkembang sejalan dengan dinamika pengetahuan masyarakat. Soetomo (2012) menjelaskan pengetahuan masyarakat tersebut merupakan manisfestasi dan implementasi dari pengetahuan lokal yang selalu berkembang melalui proses bekerja sambil belajar guna memelihara dan meningkatkan kesejahteraan, memenuhi berbagai kebutuhan, dan adaptasi dengan perkembangan lingkungan.

Oding (dalam Theresia, 2014) mencirikan kearifan lokal dengan dasar; (1) semangat kemandirian, (2) memperkuat partisipasi masyarakat dalam proses pemberdayaan, (3) menjamin daya hidup dan berkelanjutan, (4) mendorong teknologi tepat guna yang efektif dari segi biaya dan memberikan kesempatan untuk memahami dan memfasilitasi perancangan pendekatan program yang sesuai. Dengan demikian kearifan lokal secara substansial merupakan nilai dan norma yang berlaku dalam suatu masyarakat yang diyakini kebenarannya dan menjadi acuan dalam bersikap dan bertindak.

Sikap merupakan predisposisi atau kecenderungan untuk memberikan respon secara kognitif, emosi, dan perilaku yang diarahkan pada suatu objek, pribadi, dan situasi khusus dalam cara-cara tertentu (Strickland dalam Hanurawan, 2012:64). Thursione (dalam Ahmadi,2007:150) juga menyampaikan bahwa sikap merupakan tingkatan kecenderungan yang bersifat positif atau negatif yang berhubungan dengan objek. Sedangkan makna menyikapi adalah mengambil atau menentukan sikap terhadap sesuatu, dalam konteks ini terhadap objek yaitu warga retardasi mental.

Sikap ini disampaikan di atas merupakan kesadaran individu yang menentukan perbuatan yang nyata dalam kegiatankegiatan sosial. Sehingga yang dimaksud sikap masyarakat atau sosial yaitu sikap orang-orang sekelompoknya terhadap objek sosial dan dinyatakan berulang-ulang. Sikap sosial ini ditandai dengan subjeknya adalah orang-orang dalam kelompoknya, objeknya sekelompok orang, dan frekuensinya berulang-ulang. Thomas (dalam Ahmadi, 2007:152-153) menyampaikan bahwa sikap masyarakat ini sebagai suatu kesadaran yang menentukan perbuatan-perbuatan yang nyata yang akan terjadi dalam kegiatan-kegiatan sosial.

Sikap positif merupakan sikap yang menunjukkan atau memperlihatkan menerima, mengakui, menyetujui, serta melaksanakan norma-norma yang berlaku. Sedangkan sikap negatif merupakan sikap yang menunjukkan atau 
memperlihatkan penolakan atau tidak menyetujui, dan tidak melaksanakan norma-norma yang berlaku (Ahmadi, 2007:153).

Travers dan Gagne (dalam Ahmadi, 2007:151) mengungkapkan bahwa sikap meliputi tiga komponen yang saling berhubungan yaitu; (1) Kognitif berupa pengolahan, pengalaman, dan keyakinan serta harapan-harapan individu tentang objek tertentu, (2) Afektif berwujud proses yang menyangkut perasaan-perasaan tertentu seperti simpati, antipati dan sebagainya yang ditujukan kepada objek tertentu, dan (3) Konatif berwujud proses tendensi/kecenderungan berbuat sesuatu terhadap suatu objek. Misalnya kecenderungan memberi pertolongan, menjauhkan diri, dan sebagainya.

Sikap terbentuk melalui proses belajar dan hasil kontak sosial dengan lingkungannya. Proses belajar yang dimaksud seperti mengamati orang lain (belajar sosial), proses asosiasi, pengalaman langsung, dan pengamatan terhadap perilakunya sendiri (Rahman, 2013:131-132). Rahman (2013:129130) lebih lanjut menyampaikan bahwa fungsi sikap bagi individu atau sekolompok orang, antara lain: sebagai pemandu mencapai tujuan yang diinginkan dan menghindari hasil yang tidak diinginkan, memelihara dan meningkatkan harga diri, alat mengeskpresikan nilai-nilai dan konsep diri (memperkenalkan nilai-nilai atau keyakinan terhadap orang lain), dan lain sebagainya.

Banyak pendapat yang menerangkan tentang faktor-faktor yang mempengaruhi sikap, namun hanya ada beberapa saja yang dianggap penting dan determinan, yaitu; (1) faktor fisiologis, (2) faktor pengalaman langsung terhadap objek sikap, (3) faktor pengalaman pada individu memberikan pengajaran dan pengetahuan pada seseorang, (4) faktor situasi, (5) faktor norma, (6) faktor kerangka acuan, (7) faktor komunikasi sosial (Walgito, 2011:130-131).

Retardasi mental sering dipadankan dengan istilah lemah pikiran (feeble-minded), terbelakang mental (mentally retarded), dungu (idiot), gangguan intelektual, dan lain sebagainya. Sedangkan dalam psikologi klinis, orang yang mengalami retardasi mental adalah kelainan atau kelemahan jiwa dengan inteligensi yang kurang. Biasanya terdapat perkembangan mental yang kurang secara keseluruhan tetapi gejala yang utama adalah intelegensi yang terbelakang (Maramis, 2005: 386). Pendapat serupa disampaikan American Asociation on Mental Deficiency/AAMD, retardasi mental yaitu kondisi fungsi intelektual umum di bawah rata-rata (Kaplan dkk,1997:673). Hal tersebut ditegaskan Santrock (2010: 224-225) dan Durant dan Barlow (2007: 305306) bahwa retardasi mental adalah kondisi yang ditandai dengan rendahnya kecerdasan, sulit bersosialisasi, dan sulit beradaptasi dalam kehidupan sehari-hari.

Nevid, Rathus, dan Greene (2003:149-150) mengklasifikasi retardasi mental berdasarkan Intelligence Quotient (IQ) menjadi 3, yaitu; (1) debil, IQ:70-90 adalah retardasi mental ringan yang tingkatan intelegensi setara dengan anak normal berusia 7-12 tahun, bersifat educable, (2) imbecil, IQ:50-70 adalah retardasi mental sedang yang tingkatan intelegensinya setara dengan anak-anak normal usia 3-7 tahun, kemampuan membentuk konsep amat terbatas, namun trainable, (3) Idiot, IQ:0-25 adalah retardasi mental berat yang tingkatan intelegensi setara dengan anak normal berusia 1-3 tahun, bersifat tergantung karena tidak mampu hidup tanpa pertolongan orang lain. IQ ini bukan merupakan satusatunya patokan yang dapat digunakan untuk menentukan berat ringannya retardasi mental tetapi juga bisa mendasarkan pada penilaian keterampilan spesifik dan perilaku adaptif dan hasil tes psikomotorik. Dengan demikian retardasi mental merupakan hasil proses patologik di dalam otak yang menyebabkan keterbatasan terhadap intelektualitas dan fungsi adaptif.

\section{METODE PENELITIAN}

Penelitian ini dilaksanakan di Desa Sidoharjo Kecamatan Jambon Kabupaten Ponorogo dalam waktu dua tahun. Subyek penelitiannya adalah masyarakat di lingkungan sekitar warga yang mengalami retardasi mental.

Pendekatan penelitian yang digunakan yaitu kualitatifdeskriptif. Sumber data berasal dari sumber primer dan sumber skunder. Sumber primer terdiri dari para informan (pejabat pemerintah desa, tokoh; masyarakat, agama, dan pemuda, serta keluarga warga retardasi mental) yang ditentukan dengan teknik purposive-sampling. Sedangkan sumber skunder berasal dari dokumen, arsip milik pemerintah maupun nonpemerintah.

Pengambilan datanya menggunakan wawancara mendalam, observasi, dan pencatatan dokumen. Sedangkan tenik keabsahan datanya menggunakan validasi triangulasi sumber dan dianalisis data dengan model coding Strauss dan Corbin.

\section{HASIL DAN PEMBAHASAN}

\section{Gambaran Singkat Desa Sidoharjo Kecamatan Jambon}

Desa Sidoharjo merupakan desa hasil pemekaran wilayah Desa Krebet Kecamatan Jambon. Pemekaran desa ini bertujuan untuk mengintensifkan dan mengefektifkan pembangunan. Desa Krebet sebelum pemekaran memiliki luas wilayah lebih dari $25 \mathrm{Km}^{2}$, dibagi dalam 9 dukuh, dan jumlah penduduk yang mencapai 12 ribu jiwa. Kondisi tersebut tidak seimbang dengan daya dukungnya. Sarana-prasarana dan sumber daya yang tersedia tidak mampu menjangkau secara optimal beberapa dukuh di wilayah Selatan.

Untuk mengatasi berbagai masalah tersebut di atas, pemerintahan desa Krebet berupaya mencari alternatif pemecahannya yaitu perlu ada pemekaran atau pemecahan wilayah Desa Krebet. Desa Krebet dimekarkan menjadi 2 desa, wilayah desa pemekaran mencakup 3 dukuh, yaitu Dukuh Klitik, Dukuh Karangsengon dan Dukuh Sidowayah, dan desa pemekaran diberi nama Desa Sidoharjo.

Luas wilayah Desa Sidoharjo tergolong luas yaitu 1.219, 84 hektar namun tidak subur, $60 \%$ dari luas wilayah dataran dan $40 \%$ perbukitan/pegunungan, hanya memiliki satu akses jalan masuk, lantaran sisi-sisi jalannya tertutup oleh perbukitan. Hanya ada satu jalan utama setelah melewati sawah, ladang dan perbukitan. Jalan menyempit saat memasuki desa tersebut. Umumnya, jalan terbagi tiga tipe; aspal, makadam dan paping, serta tanah dengan berbagai tanjakan dan turunan khas daerah pegunungan. Jumlah penduduk Desa Sidoharjo 6.265 orang dengan mata pencaharian mayoritas sebagai tani dan buruh tani (BPS, 2014)

\section{Data Warga Retardasi Mental Desa Sidoharjo Kecamatan Jambon}

Warga retardasi mental Desa Sidoharjo berdasarkan keterbelakangan mentalnya dan kemampuan menjalani 
aktivitas hidupnya dapat diklasifikasi sebagaimana tabel di bawah ini.

Tabel 2. Data Orang Retardasi Mental Berdasarkan Kategori Retardasi Mental

\begin{tabular}{|c|c|c|c|}
\hline \multirow{2}{*}{$\begin{array}{c}\text { Kategori } \\
\text { Retardasi Mental }\end{array}$} & \multicolumn{2}{|c|}{ Jenis Kelas, Orang } & \multirow{2}{*}{ Jumlal } \\
\hline & $\mathbf{L}$ & $\mathbf{P}$ & \\
\hline Debil & 60 & 35 & 95 \\
\hline Imbesil & 10 & 20 & 30 \\
\hline Idiot & 6 & 7 & 13 \\
\hline Sub Jumlah & 76 & 62 & \\
\hline
\end{tabular}

\begin{tabular}{ccc}
\hline Jumlah & 138 & 30 \\
(Sumber: Hasil pencataan peneliti bersama FSB Tahun 2015)
\end{tabular}

\section{Kearifan Lokal Masyarakat Sidoharjo dalam Menyikapi Warga Retardasi Mental}

Masyarakat kampung idiot Desa Sidoharjo Kecamatan Jambon Kabupaten Ponorogo terutama orang tua dan keluarga sangat berat menerima kehadiran anak atau anggota baru dalam keadaan retardasi mental.Mereka mengurung diri bahkan ada yang mengucilkan diri dari pergaulan umum. Kejadian ini lambat laun mengalami perubahan, terutama dalam kurun waktu dua dasa warsa terakhir. Masyarakat pada umumnya ikut serta merasakan kesedihan, prihatin, trenyuhterhadap penderitaan yang dialami keluarga warga retardasi mental dan warga retardasi mental. Penolakan secara ekstrim dari masyarakat tidak ada, sikap masa bodoh berubah menjadi peduli. Masyarakat menerima warga retardasi mental dengan sikap menerima warga retardasi mental sebagai bagian komunitasnya. Keputusan mengambil sikap tersebut dipengaruhi oleh oleh hal-hal sebagai berikut:

1. Masyarakat meyakini bahwa anak adalah titipan Tuhan, dan anakcacat atau warga retardasi mental bukan musibah tetapi ujian yang harus dihadapi dan diperjuangkan. Masyarakat seringkali menyatakan bahwa bagaimanapun kondisinya mereka adalah anaknya dan warganya. Oleh karena itu perlu di-gulowentah yang berarti penjagaan dan pengasuhan baik fisik maupun kejiwaannya.

2. Masyarakat dalam menjalankan ajaran hidup manungso bakal ngunduh wohing pakarti (manusia akan memetik hasil atas tindakannya). Para informan menyampaikan bahwa tumindak olo lan becik iku sejatine mung kanggo awak'e dewe, manungso bakal ngunduh wohing pakarti. opo seng di tandur yoiku seng bakal thukul lan kang bakal di unduh, di ibaratke nandur pari bakal thukul lan ngunduh pari, nandur telo bakal thukul telo yo ngunduh telo (Perbuatan jelek maupun yang baik itu sebenarnya hanya untuk dirinya sendiri. Manusia akan memetik hasil perbuatanya. Apa yang di tanam itulah yang akan tumbuh dan akan di panen, seperti halnya kita menanam padi akhirnya tumbuh dan memanen padi, dan jika kita menanam telo (singkong) maka akan tumbuh singkong dan memanen singkong). Hal tersebut diimplemtasikan dalam kehidupan sehari-hari masyarakat berusaha tidak menyakiti maupun merugikan warga retardasi mental dan cenderung gemar membuat bahagianya karena dengan membuat bahagia warga retardasi mental berarti dia membuat bahagia dirinya sendiri.

Selain hal tersebut di atas juga diungkapkan bahwa urip kuwi bakal bali marang sangkanparaning dumadi (orang hidup itu akan kembali kepada Sang Penciptanya dan akan mempertanggungjawabkan perbuatannya). Oleh karena itu warga masyarakat yang sehat tidaknboleh menelantarkan warga retardasi mental. Masyarakat juga dilarang menghina warga retardasi mental dengan petuah aja nggeguyu (ngenyek) wong cacat, amarga cacate wong kuwi bisa numusi neng anake (jangan mentertawakan atau melecehkan orang cacat, karena cacatnya orang itu bisa menurun pada anaknya).

Masyarakat memiliki pandangan hidup bahwa urip iku urup (hidup itu menyala). Manusia hidup hendaknya menjadi manusia yang menyala atau mampu menerangi dan memberi manfaat bagi manusia yang lain. Sebaik-baik manusia adalah yang bermanfaat bagi yang lain.

Masyarakat masih menjunjung tinggi semangat dan kegiatan gotong royong. Para informan mengungkapkan filosofis yang dipegang teguh masyarakat yaitu $d u d u$ sanak dudu kadang, yen mati melu kelangan (bukan saudara, bukan kerabat, kalau meninggal ikut kehilangan). Ungkapan itu merupakan gambaran mengenai eratnya sistem kekerabatan di desa tersebut, dimana semua warga dihargai tanpa membedabedakan keturunan maupun hubungan darah yang ada. Setiap orang yang mau menolong orang lain dengan ikhlas tanpa mengharapkan apapun baik berupa pujian ataupun imbalan. Hal tersebut dianjurkan untuk sepi ing pamrih rame ing gawe (sepi di dalam pamrih pengharapan, ramai dalam kerja).

Masyarakat kampung Sidoharjo menjalani hidupnya dengan guyub dan saling tolong-menolong, termasuk membantu menangani warga retardasi mental. Bahkan warga masyarakat lingkungan sekitar yang tidak membantu atau menyia-nyiakan warga retardasi mental diberi atau mendapatkan sanksi sosial. Hal ini dituangkan dalam aturan-aturan yang disepakati bersama dan menjadi pedoman dan pengarah bagi warga masyarakat dalam berperilaku dengan sesamanya termasuk kepada warga retardasi mental. Biasanya orang-orang yang tidak mau bergaul, tidak peduli, atau tidak sosial mendapatkan sanksi sosial seperti tidak dibantu tatkala punya pekerjaan atau pada saat mendapat musibah atau kesusahan. Sehingga warga masyarakat desa ini menjadi peduli terhadap nasib sesama termasuk orang-orang yang mengalami retardasi mental.

Masyarakat meyakini bahwa kejadian banyak warga retardasi mental ada hubungan yang tidak harmonis antar diri manusia (mikrokosmis) dengan alam semesta (makrokosmis). Warga masyarakat walaupun mayoritas berpendidikan dasar dan menengah namun pengetahuan dan pemahamannya terhadap warga retardasi mental mulai meningkat. Masyarakat semakin memahami bahwa warga retardasi mental masih memiliki potensi yang masih dapat diberdayakan dan bukan merupakan penyakit menular.

Perilaku tokoh-tokoh masyarakat, agama, dan pemuda yang turut serta membantu warga retardasi mental menjadi teladan bagi masyarakat. Para informan menyampaikan rumongso melu ngrakasake lan wajib melu gulowentah (merasa ikut merasakan dan wajib ikut serta menjaga dan membinanya). Para tokoh tidak hanya menyampaikan dengan kata-kata tetapi juga dengan perbuatan nyata. Falsafah hidup yang pedomaninya adalah ing ngarso sung tulodho, ing madyo mangun karsa, tut wuri handayani. Pemimpin ketika di depan selain harus mampu membina, membimbing dan mengarahkan bawahannya, juga harus dapat memberi suri tauladan lewat sikap dan perbuatannya. Pemimpin ketika berada di tengahtengah bawahannya dengan penuh gairah, memberi mereka 
semangat dan motivasi untuk berkerja lebih baik, dan ketika di belakang harus memberi pengaruh dan dorongan dari belakang kepada yang bawahannya, agar bawahan tersebut berani tampil dan maju dengan penuh tanggungjawab.

Kearifan lokal tersebut di atas menjadi pendorong masyarakat menyikapi warga retardasi mental dengan melakukan tindakan-tindakan sebagai berikut.

1. Tidak menyembunyikan dan tidak mengucilkan orang yang mengalami retardasi mental. Mereka juga tidak melarang anggota keluarganya yang mengalami retardasi mental tersebut keluar rumah dan bergaul dengan orang lain. Sehingga tidak mengherankan apabila berkunjung ke kampung ini akan sering ketemu dengan orang-orang retardasi mental.

2. Mengajari anak atau anggota keluarganya yang mengalami retardasi mental agar dapat menjalani kegiatan-kegiatan pribadinya seperti makan, mandi, mencuci, buang air, berpakaian, dan lain-lainnya. Mereka tidak menyediakan waktu secara khusus untuk mengajarinya. Biasanya dilaksanakan secara langsung bersamaan dengan pelaksanaan kegiatan-kegiatan kesehariannya.

3. Memberi bantuan pangan, sandang, dan papan kepada warga retardasi mental. Bantuan pangan yang diberikan kepada warga retardasi mental tidak jauh berbeda dengan pangan yang mereka konsumsi yaitu jagung dan ketela. Jagung dan ketela yang diberikan kepada warga retardasi mental seringkali diwujudkan bahan setengah jadi (tepung) dan ada yang sudah siap konsumsi (nasi). Warga masyarakat dalam menyampaikan bantuan pangan tersebut tidak selalu mendatangi rumah warga retardasi mental, kadang kala mereka menyampaikan pada saat orang retardasi mental main ke rumahnya atau lewat jalan dekat rumahnya. Warga masyarakat, baik perempuan maupun laki-laki, baik orang tua (keluarga) maupun anak muda (sinoman) mengadakan arisan, baik di tingkat RT maupun FSB. Arisan di kampung ini ada yang unik dibandingkan dengan desa lain, yaitu arisan beras. Menurut informan, arisan beras Kagem maringi pabyantu tiyang-tiyang engkan mboten kadhah lan ciri, warga ngawontenaken nyimpen-ngampil uwos. Uwos sangking tiyang-tiyang engkang kadhan diampilaken dateng warga engkang mampu. Uwos tigang liter diampilaken selami sekawan wulan dhados sekawan liter. Anakne mboten diputer sedhanten, sbagian kagem disumbangaken dateng tiyang-tiyang mendho lan mboten gadah utawi keluarganipun (Untuk membantu orang-orang miskin dan cacat, warga membuat simpan-pinjam beras. Beras dari warga mampu dipinjamkan dengan sistem bunga beras. Beras 3 (tiga liter) dipinjamkan kepada orang yang warga mampu dalam tiga bulan menjadi 4 (empat liter). Bunganya yang berwujud beras itu tidak hanya dikembangbiakan lagi tetapi juga yang disisihkan untuk bantuan pada orang-orang miskin termasuk kepada orang-orang idiot atau keluarganya).

4. Mendidik dan melatih keterampilan hidup seperti membuat barang-barang rumah tangga dan alat-alat menggarap ladang seperti membuat tompo, tampah, kukusan, gedhek, encek, garan pacul, garan arit, keset, dan lain-lainnya. Selain itu, warga masyarakat kampung juga melibatkan dan/atau memberi pekerjaan warga retardasi mental dalam mencari pakan kambing, memelihara kambing, mengolah lahan dan hasil panen serta memberinya upah.

5. Melibatkan dalam berbagai kegiatan sosial kemasyarakatan yang ada di lingkungannya agar mampu menjalankan aktivitas sosialnya, seperti gotong royong hajatan, memperbaiki jalan, saluran air, dan lain sebagainya.

6. Membentuk organisasi untuk menangani atau membantu warga retardasi mental yaitu Forum Sidowayah Bangkit (FSB) dengan slogan ojo mung alok marang wong pekok, namung melok o mikir nasibe wong pekok (jangan hanya mengejek orang retardasi mental, tetapi ikutlah memikirkan nasibnya orang retardasi mental).

7. Melakukan ritual atau upacara adat yang berupa upacara bersih desa. Upacara tersebut diadakan setiap tahun dan biasanya dipusatkan di punden Mbah Bedong (orang yang diyakini sebagai cikal bakal masyarakat Sidoharjo). Upacara adat dilakukakan agar masyarakat terhindar dari bala atau bencana dan hidup menjadi tentram dan tenang, serta warga retardasi dapat melangsungkan hidupnya dengan baik, anak-anak yang lahir menjadi anak yang sehat dan selamat.

Akibat dari tindakan masyarakat bagi warga retardasi mental yaitu:

a) Dapat bersosialisasi dengan lingkungan sekitarnya. Mereka sesekali tertawa ketika membicarakan sesuatu yang dianggapnya lucu. Orang-orang retardasi mental mau menyapa dengan memberi salam dan mau menjawab kalau ditanya walaupun jawabannya tidak semuanya nyambung dengan pertanyaan, ikut jagongan, dan gotong-royong.

b) Dapat memasak dan membuat barang-barang atau alatalat rumah tangga seperti gedeg, theple, cikrak, encek, dan keset walaupun masih sederhana.

c) Dapat mengerjakan pekerjaan-pekerjaan rumah tangga dan di ladang secara minimal, seperti mengambil air untuk memasak, mencari dan memelihara ternak, dan mencari kayu bakar.

d) Dapat menjalankan kegiatan-kegiatan keagamaan seperti sholat, mengaji, pujian, dan mengumandangkan adzan.

e) Dapat bertingkah laku santun dan sesuai dengan norma kemasyarakat walaupun tidak semuanya. Contohnya minta ijin kalau mengambil bukan miliknya, bila berjalan lewat di dekat orang-orang yang sedang duduk, dia bilang nyuwun sewu atau derek langkung (permisi).

f) Dapat menyalurkan kebutuhan bilogis. Warga retardasi mental memiliki kebutuhan biologis. Mereka sering mencuri perhatian dan menggoda, bahkan ada yang menikah sesama warga retardasi mental dan ada juga salah satunya saja yang retardasi mental. Mereka dapat membangun rumah tangga dan keturunannya ada yang normal dan ada yang abnormal.

g) Dapat membaca tanda-tanda alam. Warga retardasi mental ketika bekerja di ladang apabila ada kilatan petir atau mendungnya tebal, mereka segera mengakhiri pekerjaan itu. Pada waktu musim penghujan, warga retardasi mental kalau keluar rumah membawa plastik sebagai bungkus badan (seperti jas hujan), atau memakai tas kresek sebagai pelindung kepala. Ada juga yang memakai daun pisang sebagai payungnya.

h) Dapat membaca, menulis, dan menghitung walaupun dalam taraf yang sederhana.

i) Dapat menikmati dan mengekspresikan kegembiraan dengan berjoged, baik itu acara dangdut, campursari, maupun reyogan.

j) Dapat mengerjakan kebutuhan pribadinya seperti buang air besar di sungai atau di jamban-jamban keluarga, mandi, mencuci, dan berpakaian.

Kearifan lokal masyarakat Sidoharjo dalam menyikapi warga retardasi mental ini merupakan kedalaman batin manusia dan 
keluasan relasionalitas dengan sesamanya, dengan Tuhan, dan dengan alam sekitarnya. Hal tersebut sejalan dengan pendapat Riyanto ed (2015:28-29) bahwa kearifan lokal dalam falsafah hidup tidak hanya lekat dengan tempat tetapi wilayah. Wilayah sebagai tempat tinggal tidak sekadar dimaknai secara geografis saja tetapi juga mengurai suatu kebijaksanaan yang kas. Kebijaksanaan ini adalah produk relasionalitas manusia dengan sesamanya, Tuhan, dan alam tempat dia bertumbuh dan berkembang. Relasionalitas sebagai relasi sehari-hari masyarakat berlanjut dalam kesadaran mendalam terhadap diri dan lingkungannya yang ditandai dengan banyaknya warga retardasi mental.

Kearifan lokal masyarakat dalam menyikapi warga retardasi mental ditunjukkan dari sikap dan tindakannya yang positif, menerima, dan berusaha membantu warga retardasi mental. Kearifan lokal masyarakat Sidoharjo memiliki kedalaman batin dan kebijaksanaan akan kehidupan dalam berbagai rupa, yaitu:

1. Keyakinan yang mendalam akan kehendak Tuhan bahwa anak cacat dan warga retardasi mental merupakan ujian yang harus disikapitanpa mengenal putus asa, dengan tawakal. Masyarakat meyakini bahwa manusia tidak lepas dari ujian dan cobaan yang semuanya mengandung arti dan pasti ada hikmahnya oleh karena itu masyarakat gulowentahwarga retardasi mental termasuk melaksanakan ritual adat agar hidup menjadi tentram dan tenang. Keyakinan tersebut menurut Azwar (2011:12) dan Hendriana (2006) berpengaruh pada sikap dan tindakan tertentu, pada norma-norma, dan pada kontrol perilaku dan apabila berinteraksi menjadi determinan bagi intensi yang pada gilirannya akan membentuk perilaku. Keyakinan ini bersifat normatif (yang diharapkan orang lain) dan memotivasi untuk bertindak sesuai dengan harapan normatif tersebut. Dengan kata lain, perilaku sosial dalam situasi tertentu dan terhadap stimulus (warga retardasi mental) tersebut ditentukan oleh kecenderungan berperilaku secara konsisten, selaras dengan kepercayaan, sehingga keyakinan dan kepercayaan warga masyarakat terhadap warga retardasi mental merupakan bentuk tendensi perilaku sosial normal terhadap warga retardasi mental.

2. Etika dan moral yang mewujud dalam sikap dan perilaku arif lingkungan sosial, bertanggungjawab secara moral terhadap lingkungan yang diwarnai dengan banyaknya warga yang mengalami retardasi mental, tidak mengucilkan, dan ikut serta membantu meringankan beban penderitaannya.

3. Norma-norma yang berupa anjuran-anjuran, laranganlarangan, sanksi, dan ungkapan yang diintenalisasikan dan disosialisasikan.

4. Nilai-nilai kemanusiaan yaitu nilai gotong royong, kebersamaan, kemufakatan, dan kepedulian. Nilainilai tersebut menurut Koentjaraningrat (2009:85), merupakan nilaibudaya terdiri dari konsepsi-konsepsi yang hidup dalam alam pikiran sebagian besar warga masyarakat mengenai hal-hal yang mereka anggap amat mulia. Sistem nilai yang ada dalam suatumasyarakat dijadikan orientasi dan rujukan dalam bertindak. Kluckohn (dalam Koentjaraningrat, 2009) juga mengatakan bahwa nilai budaya adalah konsepsi umum yang terorganisasi, memengaruhi perilaku yang berhubungan dengan alam, kedudukan manusia dalam alam, hubungan orang dengan orang danhal-hal yang diingini dan tak diingini yang mungkin bertalian dengan hubungan antara orang dengan lingkungan dan sesama manusia.
Norma-norma yang berupa anjuran diantara:

1. Menerima anak apapun kondisinya karena anak adalah titipan Tuhan yang harus diasuh secara lahir dan batin.

2. Membantu anak atau warga retardasi mental agar mampu menjalankan aktivitas pribadi, keluarga, dan sosial karena keberadaannya merupakan ujian.

3. Mengadakan upacara ritual menolak bala. Masyarakat melakukan upacara adat tolak bala yang berhubungan dengan warga retardasi mental ini merupakan manivestasi dari upaya menjaga keseimbangan antar kosmis. Ritual selamatan ini pada umumnya dipahami sebagai upacara ruwatan. Anak atau warga retardasi mental merupakan cacat. Menurut keyakinan otang Jawa, mereka itu mempunyai kekuatan gaib, orang-orang yang memiliki mana yang besar.Orang dapat mengingat kembali pada jaman para raja dahulu, mereka memelihara orang-orang cacat untuk menambah kekuatan, tetapi bagi keluarga orang biasa kekuatan gaib yang ada pada anak itu dapat pula berakibat buruk atau membahayakan keluarga orang tuannya.

Norma-norma yang berupa larangan diantaranya;

1. aja nggeguyu (ngenyek) wong cacat, amarga cacate wong kuwi bisa numusi neng anake (jangan mentertawakan atau melecehkan orang cacat, karena cacatnya orang itu bisa menurun pada anaknya).

2. ojo mung alok marang wong pekok, namung melok o mikir nasibe wong pekok (jangan hanya mengejek orang retardasi mental, tetapi ikutlah memikirkan nasibnya orang retardasi mental).

Ungkapan-ungkapan diantaranya:

1. urip kuwi bakal bali marang sangkan paraning dumadi (orang hidup itu akan kembali kepada Sang Penciptanya dan akan mempertanggungjawabkan perbuatannya).

2. urip iku urup (hidup itu menyala) (hidup hendaknya menjadi manusia yang menyala atau mampu menerangi dan memberi manfaat bagi manusia yang lain termasuk kepada warga retardasi mental

3. dudu sanak dudu kadang, yen mati melu kelangan (bukan saudara, bukan kerabat, kalau meninggal ikut kehilangan). Ungkapan itu merupakan gambaran mengenai eratnya sistem kekerabatan di desa tersebut, dimana semua warga dihargai tanpa membeda-bedakan keturunan maupun hubungan darah yang ada.

4. sepi ing pamrih rame ing gawe (sepi di dalam pamrih pengharapan, ramai dalam kerja). Masyarakat menjalani hidupnya dengan guyub dan saling tolong-menolong, termasuk membantu.

Ungkapan-ungkapan yang berupa saloka dan bebasan menurut Sartini (2009) mengandung nilai-nilai budaya yang dijadikan pedoman serta prinsip-prinsip umum dalam bertindak dan bertingkah laku. Tentu saja ungkapan-ungkapan yang bernilai positif. Nilai-nilai yang terkandung dalam ungkapan-ungkapan tersebut terdiri atas konsepsi-konsepsi yang hidup dalam alam pikiran masyarakat dan dianggap amat mulia karena nilai-nilai itu juga dianggap dapat menjadi penuntun dalam bersikap, berkata, dan bertingkah laku. Bagi warga masyarakat yang tidak peduli, tidak membantu, atau mengucikan warga retardasi mental akan mendapatkan sanksi sosial yang berupa tidak dibantu dan dikucilkan oleh lingkungan sosialnya.

Masyarakat yang mengarifi warga retardasi mental berhubungan juga dengan tokoh-tokoh masyarakat yang 
mampu menafsirkan nilai kearifan lokal kepemimpinan ke dalam pola sikap dan perilakunya sehingga masyarakat menjadikannya sebagai rujukan. Hal tersebut sejalan dengan karakteristik masyarakat desa yang berbudaya paternalistik. Hal tersebut sebagaimana yang disampaikan Soekanto dan Sulistyowati (2014) bahwa masyarakat desa cenderung menerima pandangan-pandangan atau sikap-sikap tertentu dari orang yang "dituakan" atau sesepuh dan dijadikan panutan dalam hubungan-hubungan kemasyarakatan

Kearifan lokal sebagaimana dijelaskan di atas mempredisposi tindakan masyarakat terhadap warga retardasi mental; (1) tidak menyembunyikan dan tidak mengucilkan dari pergaulan umum, (2) mengajari anak atau anggota keluarganya yang mengalami retardasi mental agar dapat menjalani aktivitas pribadi, keluarga, dan sosial, memberi bantuan pangan, dan sandang, (3) membangun rohani warga retardasi mental dengan cara melibatkan warga retardasi mental dalam kegiatan-kegiatan kerohanian dan seni, (4) melibatkan dalam berbagai kegiatan sosial kemasyarakatan, (5) membentuk Forum Sidowayah Bangkit (FSB) untuk mengoptimalisasi penanganan warga retardasi mental, (6) melakukan ritual atau upacara ruwatan untuk menjaga keseimbangan antar kosmis.

\section{KESIMPULAN DAN SARAN}

\section{Kesimpulan}

Kearifan lokal masyakat Sidoharjo dalam menyikapi warga retardasi mental merupakan hasil dari relasionalitas diantara warga masyarakat, masyarakat dengan Tuhan dan dengan alam lingkungan sekitarnya yang telah berjalan secara turun temurun. Kearifan lokal ditunjukkan dari sikap masyarakat yang menerima warga retardasi mental sebagai bagian dari dirinya dan berusaha membantunya agar mampu menjalankan aktivitas pribadi, keluarga, dan sosialnya.

Kearifan lokal masyarakat Sidoharjo tersebut dipredisposisi oleh; (1) keyakinan bahwa anak dan warga retardasi mental merupakan bagian dari ujian Tuhan yang harus disikapi dengan arif karena semua punya arti dan mengandung hikmah, (2) etika sosial dan tanggungjawab secara moral terhadap lingkungan sosial, (3) norma-norma yang berupa anjurananjuran, larangan-larangan, sanksi, dan ungkapan-ungkapan kebijaksanaan akan kehidupan.

\section{Saran}

Dalam upaya menjaga kearifan lokal masyarakat dalam menyikapi warga retardasi mental di masa yang akan datang, maka diperlukan program-program diantaranya:

1. Penguatan internalisasi, enkulturasi, dan sosialisasi roh kearifan lokal kepada generasi penerus atau pemuda,

2. Peningkatan pemahaman, kesadaran, kepedulian, dan partisipasi masyarakat menuju kondisi masyarakat yang arif lingkungan sosial dan berketahanan budaya.

\section{DAFTAR PUSTAKA}

Ahmadi, A. 2007. Psikologi Sosial. Jakarta: Rineka Cipta.

Aswar, S. 2011. Sikap Manusia, Teori dan Pengukurannya. Yogyakarta: Pustaka Pelajar.

BPS Kabupaten Ponorogo. 2014. Kecamatan Jambon Dalam Angka. Ponorogo: BPS Kabupaten Ponorogo.

Durand, M.V. dan Barlow, D.H. 2007. Psikologi Abnormal. Terjemah Helly Prajitno Soetjipto dan Sri Mulyantini Soetjipto. Yogyakarta: Pustaka Pelajar.

Hanif, M. dan Asri, D. 2013. Perilaku dan Interaksi Sosial Warga Masyarakat Kampung Idiot Desa Sidoharjo dan Krebet Kecamatan Jambon Kabupaten Ponorogo dalam Counselia Jurnal Bimbingan dan Konseling Vol. 03 No. 2. November 2013.

Hanif, M. dan Afifah, D. 2015. Asanti Emotan, Alternatif Model Pemberdayaan Warga Retardasi Mental Kampung Sidoharjo Jambon Ponorogo. Madiun: Institut Press.

Hanif, M. dan Asri, D.N. 2014. Meneropong Kampung Idiot, Perilaku Sosial terhadap Warga Retardasi Mental Sidoharjo dan Krebet. Madiun: Institut Press.

Hanurahman, F. 2012. Psikologi Sosial. Bandung: Remaja Rosdakarya.

Hendriani, W. dkk. 2006. Penerimaan Keluarga terhadap Individu yang Mengalami Retardasi Mental dalam Jurnal Insan Vo. 8 No. 2 Agutus 2006. Surabaya: Universitas Airlangga.

Kaplan, H.I. 1997. Sinopsis Psikiatri Ilmu Pengetahuan Perilaku. Jakarta: Bina Aksara.

Koetjaningrat. 2009. Pengantar Ilmu Antropologi (edisi revisi 2009). Jakarta: PT Rineka Cipta.

Maramis, W.F. 2005. Ilmu Kedokteran Jiwa. Surabaya: Airlangga University Press.

Nevid, J.S., Rathus, S.A, dan Green, B. 2005. Psikologi Abnormal (terjemahan). Jakarta: Erlangga.

Rahman, A.A. 2013. Psikologi Sosial, Integrasi Pengetahuan Wahyu dan Pengetahuan Empirik. Jakarta: PT Rajawali Grafika Persada.

Riyanto, A. Ed. 2015. Kearifan Lokal Pancasila Butir-butir Filsafat Keindonesiaan. Yogyakarta: Kanisius.

Santrock, J.W. Psikologi Pendidikan. Jakarta: Kencana.

Sartini, N.W. 2009. Menggali Nilai Kearifan Lokal Budaya Jawa Lewat Ungkapan (Bebasan, Seloka, dan Paribasa) dalam Logat, Jurnal Ilmiah Bahasa dan Sastra Vol. V No. 1 April 2009. Medan: Universitas Sumatra Utara.

Soekanto, S., dan Sulistyowati, B. 2014. Sosiologi Suatu Pengantar. Jakarta: PT RajaGrafindo Persada.

Soetomo. 2012. Keswadayaan Masyarakat. Yogyakarta: Pustaka Pelajar.

Theresia, A. dkk. 2014. Pembangunan Berbasis Masyarakat. Bandung: Alfabeta.

Walgito, B. 2011. Psikologi Sosial Sebuah Pengantar. Yogyakarta: CV Andi Offset.

Zulkarnain dkk. 2008. Kearifan Lokal Dalam Pemenfaatan dan Pelestarian Sumberdaya Pesisir dalam Jurnal Agribisnis dan Kerakyatan. Volume 1 Nomor 1 Juli 2008. Padang: Universitas Andalas. 